\title{
Degradation and Decolourisation of Textile Industry Effluents using FungiCBNR isolates.
}

\author{
1G.Karthikeyan, ${ }^{2}$.Ponmalar, ${ }^{2}$ R.Ragunathan, 2 Jesteena Johnney. \\ 1Department of Biochemistry, Kongu Arts and Science College, Erode, Tamilnadu. \\ ${ }^{2}$ Centre for Bioscience and Nanoscience Research, Eachanari, Coimbatore, Tamilnadu.
}

\begin{abstract}
-
Background: A dye is used to impart colour to a material, mainly azo dyes are the major produced synthetic dyestuffs because they are extensively used in the textile, leather, pharmaceutical and cosmetics industries.

Objective: The azo dyes are important chemical pollutants released from textile industries as unwanted effluents, so to evaluate the biodegrading ability of white rot fungi against the carcinogenic effluents.

Methods: In the present study,Pleurotus platypus could tolerate dye effluents and its maximum growth was observed at
$36^{\circ} \mathrm{C}$. Maximum rate of decolourisation was observed (95\%) when glucose and peptone was supplemented in the medium,
and within 6day. Decolourisation was confirmed by Biomass measurement and UV - VIS spectrophotometer. Further, it is
confirmed by Laccase enzyme assay and its molecular mass identified by SDS-PAGE.
\end{abstract}

Result: That white rot fungi to degrade toxic dyes enzymatically, into non-toxic product form. Then that water used to plant growth.

Conclusion: This work provides anoutline about microbial decolourisation (a bio-safety method) of dyes with highlights the application of these processes for the treatment of dye containing waste water.

Key words: Pleurotus platypus, Dye effluents, Mineral salt medium.

\section{INTRODUCTION}

Dyes are generally called as "chemicals" which binds to one of the material then to imports colour due to presence of chromophore group. Industrially, the following azo dyes are commonly used, they are Acid dye, Basic dye, Direct dye, Disperse dye, Mordant dye, Reactive dye, and Solvent dyes. The Acid, Basic, Direct and Reactive dyes are ionic. (Sudha et.al, 2014) Azo dyes are one of the largest and most versatile classes of synthetic dye. Specifically reactive azo dye has complex aromatic structures. Mainly, those dyes are stable because very difficult to degrade. (Usman Aftab et.al, 2011) These are mainly used in the textile, rubber product, paper printing, colour photography, pharmaceuticals, cosmetics, foods, and other industries. (Syed et.al, 2009)

Biodegradation is defined as biologically catalysed reduction in complexity of hazardous organic contaminants in soil, sub-surface materials, and ground water system by using microbes. (Nezha Tahri Joutey et.al, and Bhatnagar et.al, 2013)Bioremediation is a pollution control technology that uses natural biological species to catalyse the degration or transformation of various toxic chemicals to harmful forms. This process is completed is called as "mineralization". (Suad Ahmad)

Azo dyes and their metabolites are to be mutagenic and carcinogenic, that cause bladder cancer in humans and hepatocarcinoma. (Guru Prasad Srinivasan et.al, 2014) Through mineralisation, these dyes can be broken down into an aromatic amine, an arylamine to be carcinogenic and mutagenic. They reduce the efficiency of seed germination and plant growth, inhibits the elongation of shoot and roots.

Many textile mills to release millions of litre (10 to $15 \%$ ) of unwanted effluents in the form of waste water in rivers. This is toxic and harmful to environment. Employment of physicochemical methods for degradation of dyes such as adsorption, coagulation, flocculation, oxidation, filtration, nano-filtration, multiple effect evaporator, use of activated carbon and electrochemical methods. These are effective, but quite expensive. (Joshniet et al,2011and Gurulakshmi 2008) 
Compared with physicochemical methods, biological process have more interest because of their cost effectiveness, lower sludge formation, environment friendly. (Gurulakshmi2008)These organic materials can be degrade both aerobic and anaerobically. Dyes are not readily degraded by using conventional aerobic treatment systems because create environmental problem. Under an anaerobic condition, dyes are degraded by the cleavage of azo bonds. (Syed et.al, 2009)

During this process, microbes obtain carbon and energy through metabolism of organic contaminants. It includes many factors that is cell biomass concentration, contaminant, temperature, $\mathrm{pH}$, moisture, supply of nutrient, carbon and energy source, soil structure, etc. Different waste water management technique handles several industries, but lack implemention due to high cost and low efficiency. But using microbial technique includes Bacteria, Fungi, Yeast, Actinomycetes and Algae. These are degrading dyes easily. This is a cost effective methods for remove pollutant from environment. (Bhatnagar et.al, 2013)

Fungi especially representative of rot white fungi should also degrade different classes of dyes. The white rod fungi were most efficient ligninolytic microorganisms used for decolourisation of industrial effluents.For example: Phanerocheate chrysoporiumThelephora species, Gliocladium virense, Trichoderma harzianum, etc. (Lokendra Singh et.al, 2010) Various fungal treatments able to decolourise azo dyes using laccase enzymes it is a time consuming process.(Gurulakshmi 2008)Laccase based decolourization treatments are potentially advantageous to bioremediation since the enzyme is produced in larger amounts. These copper containing enzymes are oxidative enzyme detected in plants and many fungi. The solid and aqueous state dye decolourisation assay carried out laccase enzyme identification. (sathiya moorthi, et.al, 2007).

\section{MATERIALS AND METHODS}

\section{A. Organism and Dyes used}

In the present study, the organism Pleurotus platypus was used against Dye effluents. The organism is isolates CBNR institute by using nutrient medium.

B. Sample collection
Two different dye effluent samples (black and sandal) were collected in sterilised bottles from erode textile mills areas. Some physicochemical parameters of dye effluents such as $\mathrm{pH}(6)$, colour(Black and sandal) and smell were measured.

\section{Degradation of dye using medium}

For a dye degradation process choose Mineral salt medium that containing the following in $\mathrm{g} / \mathrm{l}$, Peptone 0.5 , yeast extract 0.25 , glucose $0.5, \mathrm{~K}_{2} \mathrm{HPO}_{4} 0.2, \mathrm{NaCl} 0.25$ and the medium was autoclaved at $121^{\circ} \mathrm{C}$ for 15 minutes.

After this sterilisation, medium kept in laminar chamber and add various concentration of $(10 \mathrm{ml}, 20 \mathrm{ml}$ and $30 \mathrm{ml}) 2$ Dye effluents. Then to this, inoculate the isolated Pleurotus platypus organism. It kept in shaker for degradation.

\section{Effect of temperature and $\mathrm{pH}$}

Thefungal cultures was inoculated in MSM broth containing dye effluent were incubated at different temperatures $\left(26^{\circ} \mathrm{C}, 36^{\circ} \mathrm{C}\right.$ and $\left.46^{\circ} \mathrm{C}\right)$ and different $\mathrm{pH}(4$, 5, 6 and 7). After incubation, the broth was study the growth of mycelia at dry weight and degradation at 450nm and 417 against a suitable blank.

\section{E. Effect of carbon source on dye degradation}

Degradation of dye was observed by the addition of carbon source like glucose in MSM media. After incubation, the broth was study the growth at dry weight and degradation at 450 and $417 \mathrm{~nm}$ against a suitable blank.

\section{F. Degradation study}

Each day $2 \mathrm{~mL}$ of samples were withdrawn from the flasks andcentrifuged at 8,500 rpm for 10 minutes. Collect the supernatant and the degradation pattern was studied using a UV- Visible Nano drop spectrophotometer (ELICO SL-159) at $450 \mathrm{~nm}$ and $417 \mathrm{~nm}$...

Remaining pellet was used to determine the biomass measurement for identification of mycelial growth.

The optimum day, $\mathrm{pH}$ temperature and the effect of carbon source were measured by using this above said method. 
G. Decolourization activity was calculated as

\section{Decolourisation $(\%)=$ Control Degradation / Control $\times 100$}

\section{H. Laccase enzyme assay}

Laccase activity was assayed spectrophotometrically at $465 \mathrm{~nm}$ as described by, take $1 \mathrm{ml}$ of culture supernatant, $1 \mathrm{ml}$ Guaicoal and $3 \mathrm{ml}$ phosphate buffer, mix and incubate this solution for 30 minutes at room temperature.

I. Laccase enzyme activity was measured by

\section{Laccase $(\mathrm{IU} / \mathrm{ml})=$ OD value $\times 5 \times$} Diluting Factor $\times 106 / 27.75$

\section{J. SDS-PAGE (Sodium Dodesyl Sulphate- Polyacrylamide Gel Electrophoresis)}

In order to ascertain the presence of the enzyme, SDS PAGE was carried out using the sample. Resolving gel and Stacking were prepared and poured into the gel apparatus and allowed to polymerize. Sample buffer ( $\beta$ merceptoethenol and bromophenol blue) was added into sample with volume 1:5 and the mixture was heated at $100{ }^{\circ} \mathrm{C}$ for 2 min and then spun down for a few seconds and then loaded in the wells of acrylamide polymerized gel in gel apparatus. The marker was also loaded in separate well to determine the molecular weight. The electrodes were attached to the gel apparatus and power supply was turned on at $150 \mathrm{~V}$. Electrophoresis was carried out at a constant voltage until the dye reaches about $1 \mathrm{~cm}$ from the end of the gel. Power was turned off and the gel was taken off with the help of spacer. The gel was submerged in staining solution and allowed the gel to stain overnight. Gel was then placed in destaining solution to remove background stain. Protein bands were clearly visible after destaining.

\section{K. Irrigation purpose}

The treated water was used for green gram plant growth as follows; the treated water was centrifuged $(5,000 \mathrm{rpm}$ for $20 \mathrm{~min})$ to remove such pellet. $5 \mathrm{ml}$ of treated water and added to the soil containing green gram seed. Each day an amount of $10 \mathrm{~mL}$ of treated water, dye water and mixed dye waters were added to the plants and growth was measured at $\mathrm{cm}$. Finally, the chlorophyll content was calculated using methanol and acetone extracts.

L. Chlorophyll content was calculated using following formula

\section{Chlorophyll a}

\section{$15.65 \times \mathrm{A} 663-7.340 \times \mathrm{A} 645$}

\section{Chlorophyll b}

\section{$16.37 \times$ A $645-3.140 \times$ A 663}

\section{RESULTS AND DISCUSSION}

In the present study, Pleurotus platypusis a white rot fungus effectively to degrades the toxic dye effluents into non-toxic form.

\section{A. Maintainance of fung}

Fungi was maintained on $2 \%$ malt agar medium and stored at $4^{\circ} \mathrm{C}$ and used for further studies.

B. Effect of optimum day on degradation

The optimum day was calculated for the degradation as follows, after inoculation of Pleurotusplatypus in medium to take the reading for degradation found or not, day by day, these are follows, finally we conclude that sixth day is optimum for both effluents.

Table 1: Degradation of dye by Pleurotus platypus at optimum day.

\begin{tabular}{|c|c|c|c|c|}
\hline \multirow{2}{*}{ Days } & \multicolumn{2}{|c|}{ Dye } & \multicolumn{2}{c|}{ Dye } \\
\cline { 2 - 5 } & $E 1$ & E2 & E1 & E2 \\
\cline { 2 - 5 } & \multicolumn{2}{|c|}{ Biomass in grams } & \multicolumn{2}{c|}{ \% of degradation } \\
\hline 1 & 0.11 & 0.09 & 12.14 & 18.36 \\
\hline 2 & 0.36 & 0.021 & 56.26 & 36.14 \\
\hline 3 & 0.46 & 0.049 & 63.14 & 58.26 \\
\hline 4 & 0.58 & 0.058 & 72.66 & 68.46 \\
\hline 5 & 0.62 & 0.060 & 83.40 & 74.18 \\
\hline 6 & 0.05 & 0.074 & 94.25 & 93.75 \\
\hline 7 & 0.043 & 0.022 & 63.16 & 48.34 \\
\hline
\end{tabular}




\section{Effect of $\mathrm{pH}$ on degradation}

The optimum $\mathrm{pH}$ was calculated for the degradation as follows, after inoculation of Pleurotus platypus in medium to note the $\mathrm{pH}$ day by day and the degradation was done at pH 7.0 and to get maximum decolourisation.

Table 2: To calculate the $\mathrm{pH}$ for degradation.

\begin{tabular}{|c|c|c|}
\hline pH & Effluent 1 & Effluent 2 \\
\hline 4 & $12.14 \%$ & $18.36 \%$ \\
\hline 5 & $63.14 \%$ & $58.26 \%$ \\
\hline 6 & $72.66 \%$ & $68.46 \%$ \\
\hline 7 & $94.25 \%$ & $93.75 \%$ \\
\hline
\end{tabular}

D. Effect of temperature on degradation

The optimum temperature was calculated for dye degradation analysis as follows, after inoculation of an organism in medium to note the optimum temperature and the degradation was done at temperature $36^{\circ} \mathrm{C}$ and to get maximum decolourisation.

Table 3: To optimize the degradation at specific temperature.

\begin{tabular}{|c|c|c|}
\hline Temperature & Effluent 1 & Effluent 2 \\
\hline $26^{\circ} \mathrm{C}$ & $72.66 \%$ & $68.46 \%$ \\
\hline $36^{\circ} \mathrm{C}$ & $94.25 \%$ & $93.85 \%$ \\
\hline $46^{\circ} \mathrm{C}$ & $50.22 \%$ & $36.14 \%$ \\
\hline
\end{tabular}

E. Effect of carbon source on degradation:

The different concentration of effluent 1 and 2 was added to mineral salt medium containing glucose as a carbon source with $\mathrm{pH} 7.0$ and temperature $36^{\circ} \mathrm{C}$.After completion of $6^{\text {th }}$ day incubation, the biomass and level of degradation was measured in UV- visible spectrophotometer. For effluent 1 the biomass was obtained as $0.12 \mathrm{~g}, 0.04 \mathrm{~g}$ and $0.05 \mathrm{~g}$ and its degradation level is $94.25 \%, 72.1 \%$ and $91.5 \%$ respectively at $10 \mathrm{ml}$, $20 \mathrm{ml}$ and $30 \mathrm{ml}$. Similarly for effluent 2, biomass was obtained as $0.022 \mathrm{~g}, 0.02 \mathrm{~g}$ and $0.02 \mathrm{~g}$ and its degradation level was $93.75 \%, 89.1 \%$ and $81.0 \%$ respectively.

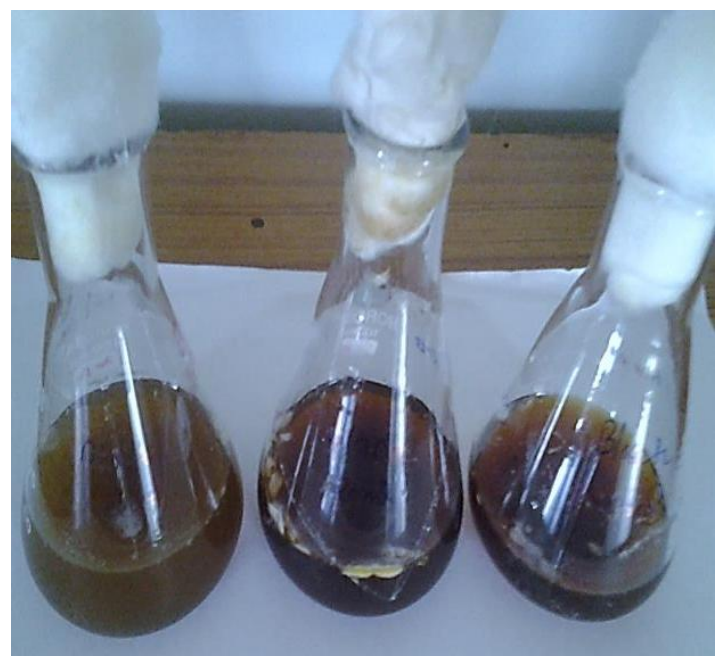

Fig.1: Degradedeffluent

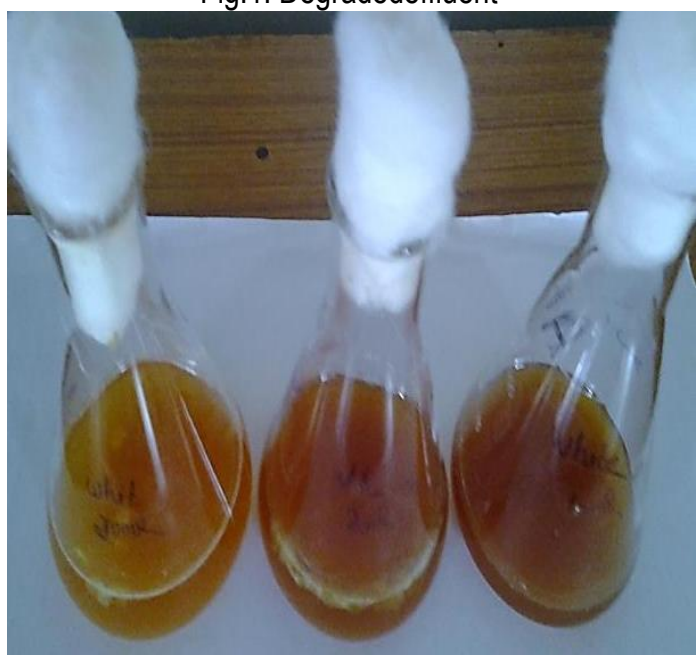

Fig.2: Degraded effluent

Chart 1: Degradation of effluents using glucose as carbon source

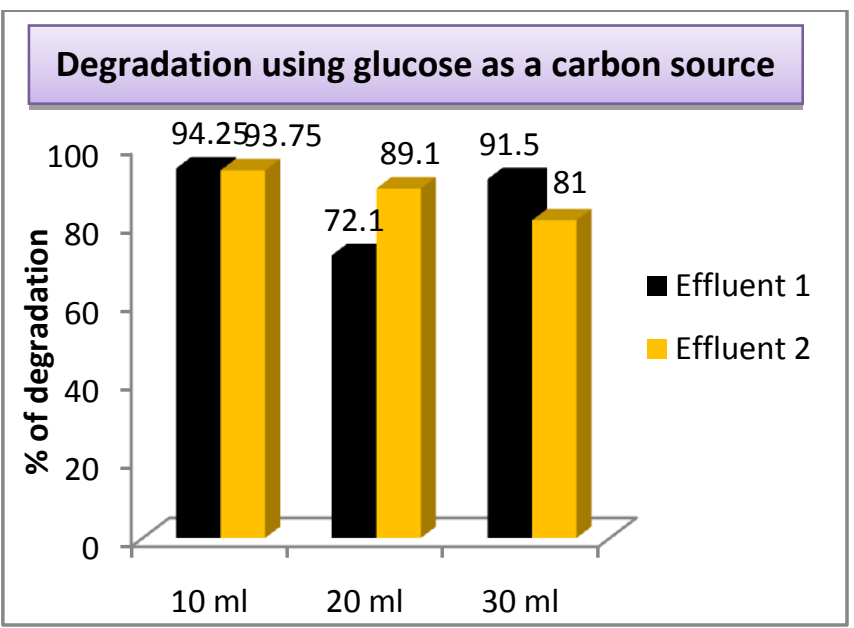




\section{F. Effect of laccase on degradation:}

Degradation of effluent 1 and 2 with glucose as a carbon source was measured by the activity of laccase using enzyme assay. Production of laccase enzyme in degraded effluents was measured in spectrophotometer and enzyme units were calculated. For effluent $1,18.3$ $\mathrm{IU} / \mathrm{ml}, 13.1 \mathrm{IU} / \mathrm{ml}, 16.8 \mathrm{IU} / \mathrm{ml}$ in $10 \mathrm{ml}, 20 \mathrm{ml}$ and $30 \mathrm{ml}$ respectively. Similarly for effluent 2, $15.6 \mathrm{IU} / \mathrm{ml}, 11.8$ $\mathrm{IU} / \mathrm{ml}$ and $10.6 \mathrm{IU} / \mathrm{ml}$ in $10 \mathrm{ml}, 20 \mathrm{ml}$ and $30 \mathrm{ml}$ of effluents respectively.

Chart 2: production of laccase enzyme using glucose

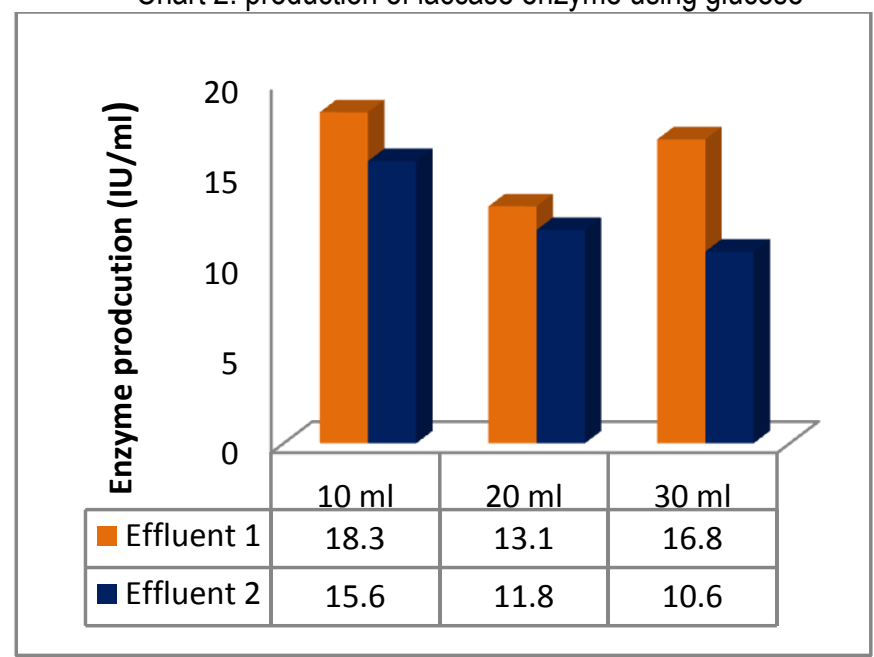

\section{G. SDS - PAGE}

The molecular weight of purified Laccase was determined by gel electrophoresis using standard marker. The partially purified Laccase revealed band on $10 \%$ SDS-PAGE with an estimated molecular weight of 60 $\mathrm{KDa}$ approximately.

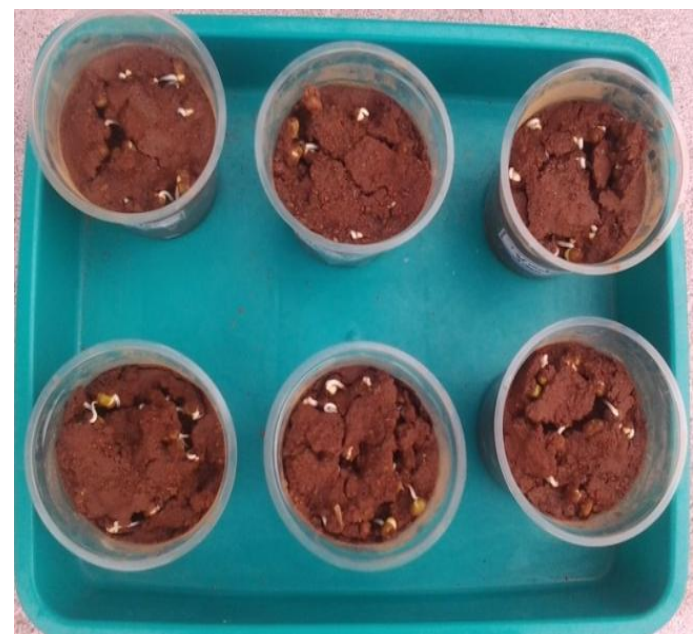

Fig.4: $1^{\text {st }}$ day

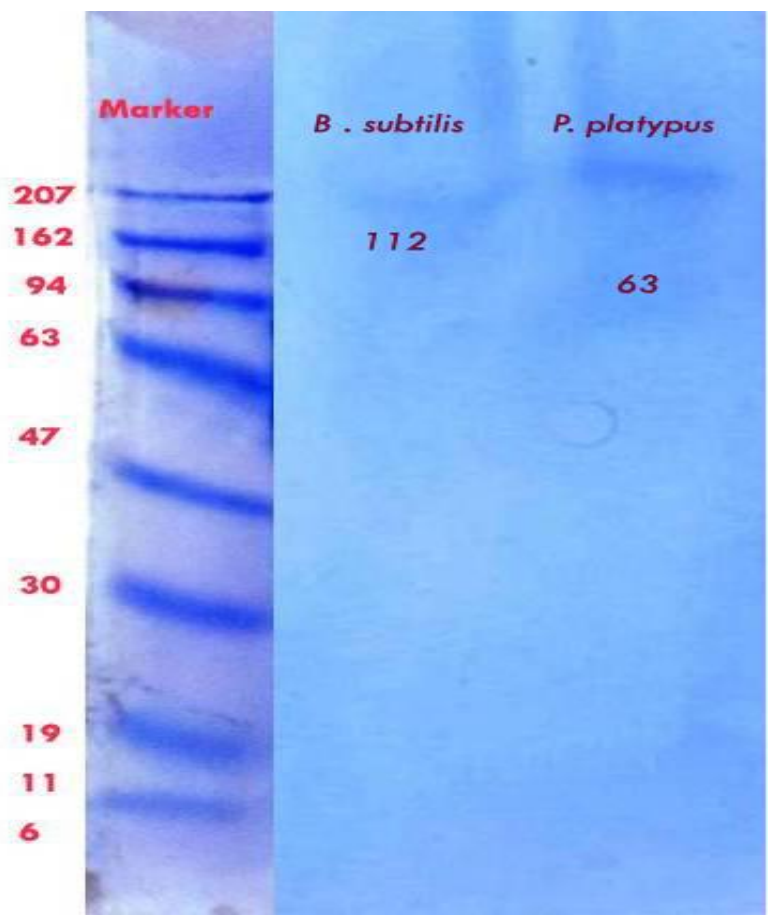

Fig.3: laccase enzyme on gel as band pattern

Finally from this calculations, to prove the Pleurotus platypus and its laccase enzyme effectively to decolourise and degrades dye effluents. Then it is used for agriculture field.

\section{H. Recycling of treated effluent:}

At last, both treated effluents were used for cultivation of green gram as in-vitro. The growth of plant has some variations compared with normal tap water that has amount of chlorophyll present in it. But still it was not toxic for agricultural environment.

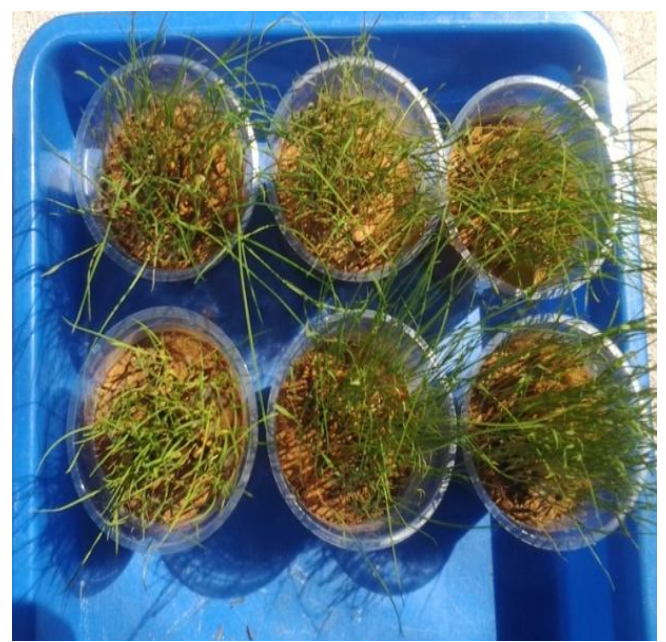

Fig.5: $3^{\text {rd }}$ day 


\section{Effect of degraded water on green gram}

Green gram leafs were analysed by find out the chlorophyll content using degraded water. Methanol and acetone solvents were used to determine the chlorophyll content and it was measured in spectrophotometer reads at $663 \mathrm{~nm}$ and $645 \mathrm{~nm}$.

Table 4: Measurement of chlorophyll a

\begin{tabular}{|c|c|c|}
\hline Categories & $\begin{array}{l}\text { Methanol } \\
\text { extract }\end{array}$ & Acetone extract \\
\hline Tap water & $9.45 \mathrm{~g}$ & $9.01 \mathrm{~g}$ \\
\hline Effluent 1 & $2.81 \mathrm{~g}$ & $1.72 \mathrm{~g}$ \\
\hline Effluent 2 & $3.62 \mathrm{~g}$ & $2.03 \mathrm{~g}$ \\
\hline $\begin{array}{c}\text { Fungi treated } \\
\text { effluent 1 }\end{array}$ & $2.92 \mathrm{~g}$ & $3.44 \mathrm{~g}$ \\
\hline $\begin{array}{c}\text { Fungi treated } \\
\text { effluent 2 }\end{array}$ & $1.88 \mathrm{~g}$ & $5.96 \mathrm{~g}$ \\
\hline Both treated & $1.14 \mathrm{~g}$ & $7.04 \mathrm{~g}$ \\
\hline
\end{tabular}

Table 5: Measurement of chlorophyll b

\begin{tabular}{|c|c|c|}
\hline Categories & Methanol extract & Acetone extract \\
\hline Tap water & $4.95 \mathrm{~g}$ & $29.72 \mathrm{~g}$ \\
\hline Effluent 1 & $1.67 \mathrm{~g}$ & $3.40 \mathrm{~g}$ \\
\hline Effluent 2 & $4.93 \mathrm{~g}$ & $19.02 \mathrm{~g}$ \\
\hline $\begin{array}{c}\text { Fungi treated } \\
\text { effluent 1 }\end{array}$ & $2.69 \mathrm{~g}$ & $18.95 \mathrm{~g}$ \\
\hline $\begin{array}{c}\text { Fungi treated } \\
\text { effluent 2 }\end{array}$ & $2.15 \mathrm{~g}$ & $4.16 \mathrm{~g}$ \\
\hline \begin{tabular}{c} 
Both treated \\
\hline
\end{tabular} & $1.26 \mathrm{~g}$ & $13.18 \mathrm{~g}$ \\
\hline
\end{tabular}

Our work is compared with other researchers as follows, textile dyes are chemicals with complex aromatic structures. A great number of dyes and other chemicals are used in textile wet processes. There are more than 105 commercially available dyes with over $1 \times 10^{6}$ tons of dye stuff produced annually world-wide. Among these available dyes, azo dyes constitute about $70 \%$ in the world that represents $70 \%$ of total dye produced per year. Thus making the largest and the most important group of synthetic colorant released into an environment.

The industrially manufactured azo dye used for textile finishing process to generate waste water stream. It is difficult to treat by conventional waste water treatment methods. For this reason to use such physicochemical methods, it has some advantages and disadvantages. But the biological methods are preferable because of economical and low possibilities of production of products likes sludge formation. (Usman Aftab et al, 2011)

But, it have also some risk such as screening of that specific micro-organism, is a one of the critical step in this remediation system. These kind of work is performed by numerous workers, is discussed as follows,

Aleksanderparko et.al, 2011, was used various techniques degrades synthetic dyes as follows, 1.Physical: Absorption, sedimentation, flotation, coagulation, membrane filtration and radiation. 2.Chemical: $\mathrm{H}_{2} \mathrm{O}_{2}$ oxidation, chlorination, reduction, ozonisation and Fenton oxidation. 3.Electrochemical: electrocoagulation, electro flotation, electro oxidation and electro reduction. 4.Biological: It includes aerobic and anaerobic bacteria, Algae, Fungi and Yeast. White rot fungi decolourise wide range of dye faster than others. For this result, he used various types of bioreactors.

Yongjie Miao, 2009 investigates microbes should degrade waste water containing dye by using following, Fungi (Phanerochaetechrysosporium, Trametesversicolor and Penicilliumgeastrivous), Bacteria (Bacillus subtilis, Pseudomonas species, E.coli and Aero Monas hydrophlia), and Yeast (Kluyveromycesmarxiamus $1 M B$ 3).

Wide ranges of economically available choices are found for their degradation purpose that is $\mathrm{pH}$, salt concentration and chemical structures. But his use most practicable biological systems but decolourisation vary. Finally, he is told more concerted efforts are require establishing biological decolourisation system.

In 1996, Ibrahim M. Banat, et.al, examines biological decolourisation of dye used in textile industries by using 
fungi (Phanerochaetechrysosporium) and bacteria (Bacillus subtilis, Aeromonashydrophlia and Bacillus cereus). From this, Bacillus subtilis have a high degrading capacity of azo dye then Aeromonashydrophlia followed Bacillus cereus. Importantly, is dealing with BOD and COD for reduction of dye complexity through aerobic biodegradation.At last Ibrahim M. Banat, et.al, says such efforts are required to establish biological decolourisation system.

Archna, et.al, in 2012, investigate conventional biological process as well as laccase process for replace energy intensive and water consuming chemical treatment operation. For this purpose, those persons choose three methods, 1. Physical: Membrane filtration and adsorption technique widely used. Adsorption technique serves as an attractive alternative treatment because inexpensive. But it cannot decolourise solution in reasonable time. (Not in use) 2. Chemical: This method removes dye but accumulation of concentrated sludge that create disposable problem and is also expensive. (Not in use) Example: Coagulation, Flocculation. 3. Biological Method: Those persons say, above two methods have such limitation so use fungal and bacterial decolourisation process, it includes azoreductase and laccase and to get a better result.

Wamik Azmi et.al, (1998) reveal Bacteria, Actinomycetes, yeast and fungi is effectively degrades Triphenyl methane dye because less sludge formation and environment eco-friendly but physicochemical parameters have several disadvantages. Different concentration of dyes used in medium for degradation, the degrading product is to be detected by using TLC, GC-MS.

From the above references, several workers degrade dye effluents by using many more microbes like bacteria, fungi and actinomycetes, and get better results. But such peoples don't implement certain things. But we use single fungi species to effectively degrade dye effluents then treated effluent was used to cultivate plant. This might reduce more water lose and improve treaded water usage.

\section{CONCLUSION}

Microbial activities are very important for the renewal for our environment and maintenance of global carbon cycle. These activities are included in the term biodegradation. The present study confirms the ability of white rot fungi, its enzyme to degrade the dye effluents with decolourising efficiency of $95 \%$, thus suggesting its application to use in many textile industries. Presence of such co-substrate like glucose and peptone is essential for attaining maximum decolourisation if dye effluents. Such approaches are ultimately successful in bioremediation of pollutants may make a difference in our ability to reduce wastes, eliminate industrial pollution and enjoy a more sustainable future.

\section{ACKNOWLEDGEMENT}

We wish to thank our Institution of Centre for Bioscience and Nano science Research, Coimbatore for providing the necessary facilities for this study.

\section{REFERENCES}

[1] AleksanderPavko, Fungal Decolourization and Degradation of Synthetic Dyes Some Chemical Engineering Aspects, 2011.

[2] Archna, Lokesh K N, Siva Kiran R R , Biological methods of dye removal from textile effluents - A review , J Biochem Tech, volume 3(5), 2012, pp: S177-S180.

[3] Gurulakshmi. M, Sudramani. D. N. P and Venba. R. Biodegradation of Leather Acid dye by Bacillus subtilis. 2008.

[4] Guru Prasad Srinivasan et.al,. Biodegradation of carcinogenic textile Azo dyes using bacterial isolates of mangrove sediment. Journal of Coastal Life Medicine, Volume 2(2) , 154-162. 2014

[5] I.Bhatnagar, F.K. Pandey, S. kumar and T. Bhatnagar. Microbial degradation of textile industry effluent.Elixir Appl. Biology 56. 2013. pp: 13305-13307.

[6] Ibrahim M. Banat, a* Poonam Nigam, h Datel Singh " \& Roger Marchant $h$, MICROBIAL DECOLORIZATION OF TEXTILE-DYE- CONTAINING EFFLUENTS: A REVIEW, Bioresource Technology 58, 1996, pp: 217-227.

[7] Joshni. T. Chacko, KalidassSubramaniam. Enzymatic Degradation of Azo Dyes. 2011. International Journal of Environmental Sciences, Volume 1, Number 6, 2014, pp: 0976-4402.

[8] Lokendra Singh and Ved Pal Singh.Microbial Degradation and Decolourisation of Dyes in Semi Solid Medium by the Fungus - Trichodermaharzianum. Environ. We Int. J. Sci. Tech. 5, 2010.pp: 147-153.

[9] M.A. Syed, H.K. Sim, A. Khalid and M.Y. Shukor.A simple method to screen for azo dye degrading bacteria. J. Environ. Biol. 30(1). 2009. pp: 89-92. 
[10] Sudha, A. Saranya, G. Selvakumar, and N. Sivakumar.Microbial degradation of Azo Dyes.International Journal of Current Microbiology and Applied Sciences. Volume 3 Number 2. 2014. pp: 670-690

[11] NezhaTahriJoutey, WifakBahafid, HananeSayel and Naima El Ghachtouli. Biodegradation: Involved Microorganisms and Genetically Engineered Microorganisms. 2013.

[12] P. Sathiyamoorthi, S. Periyarselvam, A. Sasikalaveni, K. Murugesan, P.T. Kalaichelvan. Decolourisation of textile dyes and their efffluents using white rod fungi. African Journal of biotechnology volume. 6 (4), 2007.pp: 424-429.

[13] Suad G.K. AL Ahmad. Some aerobic bacterial degradation and decolourisation of different Azo dyes. Journal of
Biology, Agriculture and Healthcare, Volume 4, Number 2, pp: 2014. 2224-3208.

[14] UsmanAftab, Muhammad Riaz Khan, Muhammad Mahfooz, Musadiq Ali, Salik Hassan Aslam and A. Rehman. Decolourization and Degradation of textile Azo dyes by Corynebacterium sp. Isolated from industrial effluent. Pakistan J. Zool., vol. 43(1). 2011. pp: 1-8.

[15] WamikAzmi, Rajesh Kumar Sani, and Uttam Chand Banerjee, Biodegradation of triphenylmethane dyes, Enzyme and Microbial Technology, Elsevier Science Inc. 1998, pp: 185-191.

[16] Yongjie Miao, Biological remediation of dyes in textile effluent: a review on current treatment technologies, pp: 10-1 to 10-10. 